\title{
TRADISI TORON ETNIS MADURA: Memahami Pertautan Agama, Budaya, dan Etos Bisnis
}

\author{
Muhammad Djakfar \\ Fakultas Ekonomi UIN Maulana Malik Ibrahim Malang \\ Jalan Gajayana No. 50 Malang, Telp. 08155524601 \\ email:mdjakfar@yahoo.co.id
}

Abstract

Toron or back to the village has been performed as a tradition among the Madurese with various reasons. In addition to Idul Fitri, the Prophet's Birth Month is an important moment for the Madurese to go back to their hometown, especially for those who come from the village and work in informal sectors in other cities. In understanding the toron tradition which has been a lulture of its own, there is a question whether there are relationships between religious values, culture, and business ethics among the Madurese, who are widely known as a hardworking community. This study uses qualitative approach and phenomenological method in order to be able to understand deeper on what the relationship among those three aspects, which can be apprehended from the toron tradition. Informants were purposively selected to those working in informal sectors and who have been working outside the Madura island. The data were collected by using observations, in-depth interview, and documentation. The results show that among the students of Islamic boarding schools, the motive of doing toron in commemorating the Prophet's birthday, is to honour the Prophet, and such celebration is just like a haul for the parents. Due to the presence of such respect, it is expected that they will receive blessings and help from the Prophet. On the other hand, for those non learners of such boarding schools, commemoration the Prophet's Birthday is just like a way (tawassul) to expiate a sin with an expectation to receive blessing from the Prophet, although they realize that they do not do his teachings. Commemorating the Prophet'sBirthday in their home village is a prestige which reflects their business success outside the island in foreign places, which normally need a big amount 
of funding. Due to that reason of commemoration, we can understand that there are relationships between religion, culture, and business ethics among the Madurese.

Toron (pulang kampung) telah mentradisi di kalangan etnis Madura dengan berbagai motifnya. Selain hari raya, bulan Maulid Nabi merupakan momen penting bagi etnis Madura untuk pulang kampung, terutama bagi mereka yang berasal dari pedesaan yang bekerja di sektor informal di rantau orang. Dalam memahami tradisi toron yang telah membudaya, adakah pertautan antara nilai agama, budaya, dan etos bisnis di kalangan etnis Madura yang dikenal sebagai komunitas pekerja keras. Inilah sejatinya pokok masalah yang akan dipahami melalui penelitian ini. Penelitian ini menggunakan pendekatan kualitatif dengan metode fenomenologi untuk dapat memahami lebih dalam seputar bagaimana pertautan antara ketiga aspek tersebut yang dapat dipahami dari tradisi toron. Para informan sengaja dipilih bagi mereka yang bekerja di sektor informal yang telah merantau ke luar pulau Madura. Data digali dengan metode observasi, wawancara mendalam, dan dokumentasi. Hasil menunjukkan, di kalangan santri, motif toron untuk memperingati Maulud adalah untuk menghormati Rasul, dan peringatan itu diibaratkan acara haul bagi kedua orang tua mereka. Dengan rasa hormat itu diharapkan rahmat dan syafaat nabi kelak akan didapat. Sebaliknya, bagi kalangan non santri, mengadakan acara Maulud ibarat wahana (tawassul) untuk menebus dosa dan kelak berharap syafaat dari Rasul, sekalipun mereka merasa tidak menjalankan ajarannya. Memperingati Maulud di kampung halaman merupakan prestise yang mencerminkan sukses bisnis mereka di negeri orang yang membutuhkan cukup banyak biaya. Sebab dari peringatan itulah dapat dipahami ada pertautan antara agama, budaya, dan etos bisnis di kalangan muslim etnis Madura.

Key words: toron tradition, business ethics, the Madurese

\section{Pendahuluan}

Toron (pulang kampung) merupakan sebuah tradisi yang turun-temurun di kalangan etnis Madura, yakni bagi mereka yang telah berdomisili di luar pulau Madura. Semua orang Madura bebas melakukannya sesuai dengan motif masing-masing artinya, tradisi toron tidak mengenal batas sosial apa pun karena setiap orang mempunyai ikatan primordial dengan kampung halaman tempat mereka dilahirkan. Dengan demikian, tradisi toron telah biasa dilakukan oleh komunitas Madura yang melakukan migrasi ke luar Madura dengan alasan untuk mengubah nasib karena tempat asal yang kurang menjanjikan secara ekonomi.

Namun demikian faktor pendorong migrasi itu tentu saja tidak tunggal, artinya semata-mata karena alasan ekonomi, karena dalam kenyataan masih banyak alasan lain seperti karena terjadi perang, keamanan, bencana alam, 
perkawinan dan lain sebagainya (Kesuma, 2004: 27).

Selain itu dari aspek inisiasi, bisa terjadi karena atas kehendak sendiri secara individual yang dikenal dengan migrasi swakarsa. Atau, karena kehendak pihak lain, misalnya dari pemerintah agar terjadi pemerataan penduduk di seluruh nusantara, maka diciptakanlah sebuah program nasional yang dikenal dengan transmigrasi. Sedangkan dari aspek daerah tujuan (sasaran), bisa jadi penduduk pindah dari pedesaan ke daerah perkotaan yang dikenal dengan urbanisasi. Semua ini tentu saja mereka melakukannya dengan motif yang sama, yakni mencari daerah baru dengan tujuan membangun suasana baru yang lebih prospektif untuk masa depan diri dan keluarganya.

Migrasi diartikan sebagai perubahan tempat tinggal secara permanen. Dalam hal ini, antara lain sebagaimana yang dilakukan oleh etnis Madura ke berbagai pulau di nusantara, terutama di pulau Jawa (Lee, 1976: 5). Di pulau ini mereka banyak bermigrasi ke daerah Surabaya (termasuk Malang) sampai ke arah ujung timur, yakni Banyuwangi, yang secara politis akhirnya dikenal dengan daerah tapal kuda, selain itu ada juga yang pindah ke pulau lain seperti Kalimantan, Sumatra, Bali, dan lain-lainnya.

Demikian pula migrasi yang dilakukan etnis Minangkabau di Sumatra Barat dan etnis Bugis di Sulawesi. Kedua etnis ini mengandung sisi persaman dengan etnis Madura sebagai etnis petualang yang banyak menekuni sektor informal di mana mereka menetap di daerah tujuan. Etnis Minangkabau dengan ikon "Rumah Makan Padang"-nya yang sudah sangat populer di kalangan masyarakat luas. Sama halnya dengan etnis Bugis yang menyebar ke berbagai pulau. Bahkan tidak sedikit etnis ini yang hijrah ke manca negara, tepatnya, Johor dan Selangor Malaysia sebagaimana yang pernah diteliti oleh Andi Ima Kesuma (Kesuma, 2004: 91-136).

Akan tetapi di balik semua itu suatu hal yang perlu disadari bahwasanya para migran itu pada suatu saat tetap berkeinginan untuk pulang kampung dengan berbagai motif yang ikut mendorong mereka. Secara psikologis dalam diri mereka ada kecenderungan untuk melihat kampung halaman yang membesarkannya. Terlebih lagi secara sosiologis, mereka masih mempunyai hubungan kekerabatan dengan keluarga besar di daerah asal, seperti kedua orang tua, mertua, saudara-saudara dekat maupun jauh, dan lain sebagainya yang secara syar'i maupun kultur mewajibkan mereka untuk bersilaturrahim.

Khusus bagi etnis Madura, yang bermigrasi ke luar pulau, sewaktu-waktu atau dalam momen-momen tertentu mereka banyak yang pulang kampung (toron) yang telah mentradisi dalam jangka waktu yang sedemikian lama. 
Ditengarai, mereka melakukan tradisi toron itu, selain karena momen dua hari raya (Idul Fitri dan Idul Adha) sebagaimana yang dilakukan banyak etnis di Indonesia, namun ada momen-momen lain yang secara khusus dilakukan oleh mereka, yakni acara Maulud Nabi SAW, perkawinan, dan acara selamatan keberangkatan maupun kepulangan dari ibadah haji.

Selanjutnya permasalahannya adalah apakah ada pertautan antara tradisi toron itu dengan etos bisnis di kalangan mereka yang dikenal sebagai salah etnis pekerja keras, ulet, pantang menyerah, dan sebagainya. "Etos" secara umum diartikan sebagai sikap, pandangan, pedoman, atau tolok ukur yang ditentukan dari dalam diri seseorang atau sekelompok orang dalam berkegiatan (Rifai, 2007: 347). Etos kerja etnis Madura sangatlah tinggi karena secara naluriah bagi mereka bekerja merupakan bagian dari ibadahnya sesuai dengan ajaran Islam yang dianutnya, karena itu bagi etnis Madura, tidak ada satu pun pekerjaan yang dianggap berat, kurang menguntungkan, atau hina, selama pekerjaan itu tidak dianggap maksiat sehingga hasilnya akan halal dan diridhai sang Maha Penciptanya (Rifai, 2004: 347). Itulah sekilas sosok etnis Madura yang menjadi objek dalam penelitian ini.

\section{Etnis Madura: Komunitas Migran yang Pantang Menyerah}

Dalam kenyataan, etnis Madura, menyebar ke berbagai pelosok tanah air, bahkan tidak jarang yang lintas negara. Karena keuletannya yang banyak menekuni kewirausahaan sehingga pantaslah bagi mereka mendapat predikat "pahlawan" ekonomi di Indonesia.

Mereka pantang menyerah menghadapi arus globalisasi ekonomi yang tidak mungkin dibendung, kendati dari aspek permodalan, sumber daya manusia, dan sistem menajemen yang relatif terbatas. Namun demikian, dengan modal kerja keras eksistensi mereka tetap diperhitungkan oleh masyarakat, dan bahkan layak menjadi "ikon" perkembangan bisnis kelas menengah ke bawah di Indonesia (Djakfar, 2009: 148).

Tak dapat dipungkiri, di berbagai sudut kota di Indonesia, khususnya di wilayah perkotaan di Jawa dan Kalimantan, keberadaan etnis Madura mudah sekali dikenali sebagai kaum pekerja keras yang menggeluti berbagai kegiatan ekonomi yang sering dikelompokkan dengan sebutan sektor informal. Karenanya, secara populer, migran Madura seringkali diasosiasikan dengan berbagai label seperti penjual sate, soto, tukang becak, tukang cukur, kuli angkut, kuli bangunan, dan semacamnya (Subaharianto dkk, 2004: 11).

Kuatnya tradisi migrasi di kalangan etnis Madura sebenarnya merupakan 
bentuk jawaban terhadap kondisi ekologis pulau Madura yang gersang dan tandus yang miskin daya dukung yang memadai untuk memenuhi kebutuhan populasi dalam jumlah besar yang terus berkembang. Dengan demikian, migrasi menjadi alternatif yang sangat signifikan sekali, bukan saja untuk mengurangi tekanan ekonomi dan sosial, melainkan juga menjadi sarana untuk mewujudkan perbaikan hidup yang diidealkan. Bahkan, pada periode tertentu di masa lalu, migrasi bagi etnis Madura juga menjadi strategi penting untuk menghindari kekuasaan tradisional yang opresif dan eksploitatif (Subaharianto dkk, 2004: 11).

Nampaknya, perbaikan ekonomi itu merupakan alasan utama yang mendorong seseorang untuk melakukan migrasi ke berbagai tempat yang lebih menjanjikan, terutama daerah perkotaan. Di samping untuk perbaikan pendidikan, tempat tinggal, dan lain sebagainya yang kesemuanya itu sebagai rasa tanggung jawab kepada keluarga (Lee, 1985: 40).

Secara historis, dikenal dua pola migrasi yang terjadi di kalangan etnis Madura, yaitu yang pertama, migrasi temporer atau disebut migrasi musiman (seasonal migration), sedangkan yang kedua pola migrasi permanen (permanent migration). Migrasi pola yang pertama, umumnya terjadi pada musim kemarau atau setelah masa tanam di mana pekerja migran meninggalkan pulau (onggha) dan baru kembali (toron) setelah masa panen, atau pada akhir Ramadhan, untuk berpesta bersama keluarga. Mereka biasanya tinggal di Jawa selama tiga sampai enam bulan atau dua minggu sampai satu bulan. Para pedagang biasanya tinggal lebih lama, enam bulan atau lebih (Kuntowijoyo, 2002: 78).

Pada tahun 1911, Komisi Kesejahteraan melaporkan bahwa karakteristik pekerja-pekerja migran temporer dari Bangkalan adalah laki-laki yang belum menikah, tidak memiliki tanah pertanian atau anak-anak. Sedangkan yang dari Sumenep juga laki-laki, namun sudah menikah (Kuntowijoyo, 2002: 79). Menurut hasil penelitian BAPPEDA Jawa Timur dan PAPIPTEK LIPI, sekitar 75\% masyarakat Madura tinggal di luar pulau Madura, sedangkan sisanya yang tinggal di Madura hanya 25\% (Subaharianto dkk, 2004: 30). Menurut data BPS provinsi Jawa Timur pada tahun 2000, populasi Madura sebanyak 3.117.000 jiwa, sedangkan tahun 2007 diperkirakan mencapai 3.250.000 jiwa (Rifai, 2007: 30). Apabila menggunakan asumsi yang tinggal di luar pulau sebanyak tiga kali lipat (75\%) hasil sudah pasti tinggal mengalikan dengan jumlah yang tinggal di pulau Madura. 
Namun demikian pola migrasi seterusnya tak banyak diketahui secara pasti. Hanya saja untuk saat ini, dengan perkembangan informasi dan transportasi, nampaknya mobilitas etnis Madura untuk bermigrasi ke berbagai pelosok tanah air atau mancanegara semakin tinggi. Motif yang dominan adalah untuk perbaikan ekonomi diri dan keluarga, sebagaimana teori migrasi yang menyatakan ada tiga penyebab timbulnya migrasi, yaitu faktor pendorong (push factor), faktor penarik (pull factor), dan kemungkinan perpindahan (Kesuma, 2004: 32).

Berdasarkan teori tersebut, faktor pendorong (push factor) migrasi etnis Madura antara lain karena kondisi geografis yang tidak menjanjikan secara ekonomi, sehingga memaksa mereka untuk pindah ke tempat lain yang menjanjikan atau mempunyai daya tarik perbaikan nasib di kemudian hari. Untuk jelasnya, faktor penariknya (pull factor) secara umum karena local socioeconomic conditions and the characteristic of the potential places (Lee, 1985: 119). Karena faktor inilah antara lain yang bisa menjadikan etnis Madura pantang menyerah dalam bekerja demi perbaikan ekonomi mereka. Sedangkan yang dimaksud karena kemungkinan perpindahan, misalnya karena bencana alam, sehingga alternatif yang harus dipilih oleh sebuah komunitas harus pindah ke tempat lain yang lebih aman di masa depan.

\section{Tradisi Toron: Konstruks Agama, Budaya, atau Sosial?}

Istilah toron atau mudik (pulang kampung atau pathobin) rasanya merupakan hal yang biasa karena bisa terjadi di kalangan berbagai bangsa dan etnis di dunia. Istilah toron merupakan kebalikan dari istilah onggha, dalam arti migrasi ke tempat lain yang dituju (emigrasi). Dengan demikian muncul istilah toron, tidak lepas karena ada aktivitas perpindahan (onggha) yang mendahului. Bagi etnis Madura syarat onggha harus terjadi perpindahan ke luar pulau, sehingga jika terjadi perpindahan masih dalam kawasan pulau Madura, maka hal itu belum dapat dikatakan onggha.

Hanya saja pertanyaannya adalah apakah tradisi toron itu merupakan produk budaya atau agama (religion). Menurut asumsi penulis, tradisi toron sebenarnya termotivasi kuat ajaran agama, hanya saja pola pelaksanaannya tidak lepas karena pola budaya. Bukankah ajaran agama tidak secara detail mengatur, bagaimana pemeluknya melakukan praktik peribadatan, terutama ibadah yang ghairu mahdhah. Karenanya di sini kultur lokal mendapat ruang untuk mewarnai bentuk-bentuk peribadatan yang dilakukan komunitasnya, termasuk mengekspresikan tradisi toron yang telah lama dipratikkan oleh 
etnis Madura. Di sisi lain, bagaimanapun tradisi toron itu sendiri lahir dari sebuah proses interaksi sosial dalam ruang publik dengan berbagai ikatan normatifnya.

Berbagai motif tradisi toron di kalangan etnis Madura antara lain bisa dipahami dari identitas mereka sebagai Muslim yang mempunyai karakter, antara lain mereka bercita-cita kuat untuk bisa naik haji, dan bahkan sangat bangga menyandang predikat "haji". Selain itu mereka sedemikian hormat terhadap kyai (pemuka agama), menjunjung tinggi hari-hari besar keagamaan, mengapresiasi pendidikan agama, dan kebiasaan membangun mushala/langgar (Triyuwono, 2009: v).

Oleh karena sedemikian kuat perhatian etnis Madura terhadap hari-hari besar Islam, sehingga mereka yang ada di rantau selalu meluangkan waktu agar bisa pulang kampung (toron), selain juga karena ada motif lain. Seperti keperluan ta'ziyah karena ada keluarga yang meninggal, acara perkawinan, ziarah kepada anggota keluarga yang akan berangkat maupun pulang dari ibadah haji, sowan (acabis) kepada kyai, ziarah kubur kedua orang tua, dan lain sebagainya (Arifin, 2007: 255). Kendati ini semua bersifat insidental, namun aktivitas semacam ini telah mentradisi di kalangan etnis Madura.

Hari-hari besar Islam seperti Maulud Nabi Muhammad SAW, terutama Idul Fitri (tellasan aghung) dan Idul Adha (tellasan reraja, tellasan ajjih) selalu diperingati secara meriah (Rifai, 2007: 46). Sebagai etnis yang agamis dan hidup dalam sebuah kultur lokal yang secara turun temurun terus dilanggengkan, sebagian pakar ada yang berpendapat ada tiga momen penting yang justru sangat mendapat perhatian, selain Idul Fitri dan Idul Adha yaitu acara penghormatan atas kematian anggota keluarga dengan mengadakan tahlilan hari ke-1 sampai ke-7, 40 hari, 100 hari, dan 1000 hari, sebagai indikasi mereka pengikut ahlus sunnah wal jamaah bermadzhab Syafii (Rifai, 2007: 42-50).

Selain itu acara Maulud Nabi dan acara selametan keberangkatan dan kedatangan ibadah haji keluarga, kedua momen ini masih sangat sakral di kalangan etnis Madura yang menjadi salah satu motif mereka merasa wajib pulang kampung (toron). Tradisi semacam ini sejatinya merupakan sebuah ekspresi perilaku beragama dalam bingkai kultur yang terus hidup di kalangan mereka. Sehingga dengan demikian tradisi toron di kalangan etnis Madura menurut peneliti adalah merupakan hasil dari sebuah konstruks sosial, sekaligus konstruks agama dan budaya yang ada, atau untuk jelasnya, tradisi toron adalah merupakan hasil interaksi sosial antar individu dalam sebuah komunitas yang di dalamnya terikat oleh nilai-nilai agama maupun kearifan 
lokal yang berlaku dan sekarang tradisi ini telah menjadi milik dan bagian dari kepribadian mereka.

\section{Etos Bisnis: Sebuah Pertaruhan Harga Diri}

Membincang masalah kewirausahaan (entrepreneurship) di kalangan masyarakat Muslim, tidak jarang muncul kesan minor yakni, terbelakang, kurang maju. Stigma ini adalah wajar, karena sementara ini kondisi sebagian besar negara-negara Muslim belum maju secara ekonomi (Djakfar, 2009: 31). Sebagaimana nampak di wilayah-wilayah kawasan Afrika maupun Asia, akan menunjukkan betapa lemahnya penguasaan ekonomi masyarakat Islam (Effendy, 2001: 195). Penyebabnya adalah karena menurut tesis Max Weber, Islam dianggap tidak mempuyai afinitas teologis dengan pengembangan kapitalisme, tidak seperti ajaran Protestan, khususnya dari sekte Calvinis puritan. Karena itu, kendati menganut sistem "monoteistis universalistis," namun Islam masih dianggap sebagai agama kelas prajurit, mempunyai kecenderungan pada kepentingan feodal, berorientasi pada prestise sosial, bersifat sultanistis, bersifat patrimonial birokratif, serta tidak mempunyai prasyarat rohaniah bagi pertumbuhan kapitalisme (Abdullah, 1979: 19-20).

Tesis Weber itu dianggap lemah sehingga melahirkan banyak resistensi (antitesis) berdasarkan bukti-bukti empirik. Antara lain, Clifford Geertz, dengan studi antropologisnya pada masyarakat santri Mojokuto (Pare, Jawa Timur) yang mempunyai kegairahan ekonomi dan semangat kerja yang sangat kuat (Effendy, 2001: 203). Selain itu, Robert N. Bellah yang menggambarkan bagaimana etos kerja penganut ajaran Tokugawa dan Budhisme Zen di Jepang. Pakar lain, Robert W. Hefner, memberikan persaksian dengan mengemukakan bagaimana ide-ide besar Muhammadiyah dalam turut serta memajukan perekonomian di Indonesia. Ia mengatakan, "dilihat dari kenyataan, sama sekali tidak kebetulan jika para intelektual Muhammadiyah adalah satu-satunya konstituen non pemerintah yang paling berpengaruh dalam pembentukan BMI di kemudian hari" (Hefner, 1998: 261). Pandangan mereka ini merupakan sebuah persaksian bahwa ajaran teologis selain Protestan pun ternyata juga mengajarkan etos kerja kepada umatnya, tidak sebagaimana yang dituduhkan Weber dengan tesisnya yang kurang mendasar,

Lebih jauh, nampaknya tesis Weber itu pun sejatinya tidak berlaku bagi etnis Madura yang mayoritas sebagai Muslim. "Orang Madura tidak takut kehilangan tanah atau hartanya, akan tetapi mereka takut kehilangan pekerjaannya," (Kuntowijoyo, 2002: 592). Pernyataan ini ditafsirkan oleh 
Rifai, “oreng Madhura ta' tako' mate, tape tako' kalaparan.” Maksudnya, orang Madura tidak takut mati karena hal itu sudah merupakan takdir Tuhan yang tidak mungkin dihindari. Tetapi mereka takut lapar karena kelaparan tidak lain disebabkan oleh ulah dirinya yang tidak rajin dan kerja keras dalam bekerja (Rifai, 2007: 347). Karena itu salah satu karakter etnis Madura yang sangat terkenal adalah mereka pekerja keras, rajin, sungguh-sungguh, dan mau bekerja keras. Bahkan menurut Soeroso, dengan banyaknya pondok pesantren dan kepatuhan terhadap kyai, nampaknya juga berpengaruh terhadap jiwa wiraswasta etnis Madura karena pendidikan pondok pesantren secara nyata mampu mendidik insan yang mandiri (Soeroso, 1996: 4). Saat ini di Madura, terdapat 1157 pondok pesantren, dengan rincian, Bangkalan 236, Sampang 278, Pamekasan 404, dan Sumenep 239 (Data Kanwil Kemenag Jatim, 2012).

Bagi etnis Madura kerja keras adalah simbol harga diri atau pertaruhan diri di tengah keluarga dan masyarakat luas, sehingga apabila ada yang malas berarti tidak mempunyai harga diri dan sangat aib bagi mereka. Karena itu dalam bekerja mereka tidak memilih jenis pekerjaan apa pun, karena yang dikejar adalah hasilnya sebagai penyambung hidup.

\section{Metode Penelitian}

Penelitian ini merupakan penelitian kualitatif dengan menggunakan analisis deskriptif yakni metode yang memfokuskan perhatiannya pada prinsip-prinsip umum yang mendasari satuan-satuan yang bertemali dengan fokus masalah tradisi toron dan etos bisnis etnis Madura. Ditetapkannya etnis Madura sebagai objek penelitian, karena berdasarkan pengamatan sebagian besar masyarakat, tanpa kecuali peneliti sendiri, etnis Madura mempunyai kultur unik. Antara lain tradisi toron (pulang kampung atau pathobin) dalam momen-momen keagamaan tertentu yang dilakukan secara turun-temurun. Namun demikian di sisi lain mereka dikenal pula sebagai salah satu etnis yang mempunyai etos kerja yang tinggi, sehingga dengan demikian perlu dipahami adakah pertautan antara tradisi toron (mudik) yang termotivasi ajaran agama dan telah membudaya dengan etos kerja mereka.

Tentu saja asumsi dasar dari pendekatan ini hanyalah sebatas bentuk luar (eksternal) dari ungkapan manusia yang mempunyai pola konfigurasi dalam yang teratur (internal), yang dapat dilukiskan kerangkanya dengan menggunakan metode fenomenologi (Dhavamony, 1995: 42-43). Pendekatan fenomenologis sejatinya tidak hanya menghasilkan suatu deskripsi mengenai fenomena yang dipelajari dan tidak pula bermaksud menerangkan hakikat 
filosofis dan fenomena itu sendiri, sebab fenomenologi bukanlah deskriptif atau normatif belaka. Namun demikian, metode ini memberikan kepada kita, arti yang lebih dalam dari suatu fenomena yang diteliti, sebagaimana dihayati dan dialami oleh komunitasnya sendiri. Ini berarti perlu ada upaya untuk memahami bagaimana tradisi toron etnis Madura menurut sudut pandang, persepsi, dan pemahaman mereka sendiri atau dengan kata lain, penelitian ini berupaya memahami perspektif emik, untuk kemudian dikonstruks menjadi perspektif etik.

Dengan demikian, dalam hal ini peneliti mencoba dan mengangkat serta menginterpretasikan setiap aktivitas atau yang berkaitan dengan tradisi toron dan bagaimana relasinya dengan etos bisnis etnis Madura secara lebih dalam. Karena itu lokasi penelitian ini dilakukan di pulau Madura sebagai tempat pulang kampung, selain pula kota Malang dan Surabaya sebagai representasi di mana mereka merantau sebagai pelaku bisnis.

Adapun teknik pengumpulan data yang digunakan adalah observasi, wawancara, dan dokumenter. Dengan teknik ini dimaksudkan untuk merekam aktivitas objek dalam hubungannya dengan masalah sosial, ekonomi, dan keagamaan. Melalui pengamatan dapat dicatat tentang perilaku toron yang dianggap menarik dan penting yang apabila ditanyakan mungkin sulit untuk dijawab. Dalam hal ini penulis mengamati langsung performace mereka, misalnya gaya berpakaian, kendaraan yang dipakai, dan aktivitas yang dilakukan selama di kampung halaman. Dalam momen acara Maulud Nabi SAW misalnya, penulis sengaja minta ijin untuk hadir kepada shahibul bait dan mengikuti acaranya sampai dengan selesai.

Sedangkan sumber data adalah para perantau pelaku sektor informal yang biasa mudik (toron) ke kampung halamannya di Madura. Selain juga sumber lain yang dianggap relevan yang banyak memahami seputar masalah dalam penelitian, seperti kyai atau tokoh masyarakat di daerah penelitian.

\section{Hasil Penelitian dan Pembahasan \\ Pulau Madura: Sebuah Gambaran Umum}

Pulau Madura di lingkungan tata pemerintahan provinsi Jawa Timur merupakan Koordinator Wilayah V, yang terdiri atas empat daerah kabupaten, yaitu Bangkalan, Sampang, Pamekasan, dan Sumenep. Pulau yang dikenal sebagai pulau "Garam" ini terletak di timur laut pulau Jawa dengan koordinat sekitar 7 derajat lintang selatan dan antara 112 derajat dan 114 derajat bujur timur yang terbagi beberapa pulau besar dan kecil. Pulau Madura adalah yang 
terbesar yang dikelilingi pulau-pulau yang lebih kecil, seperti Puteran, Sapudi, Raas, Kangean, dan pulau-pulau lain yang lebih kecil yang jumlahnya lebih dari 100, baik yang berpenghuni maupun yang tidak berpenghuni (Wiyata, 2002: 30).

Rentangan pulau ini dari ujung barat ke timur mencapai panjang sekitar $160 \mathrm{~km}$ dan bagian terlebar utara ke selatan $40 \mathrm{~km}$ dengan luas daratan sekitar 4200 km2 Sedangkan untuk seluruh wilayah kurang lebih 5168 km2. Panjang daratan untuk seluruh wilayah mencapai sekitar $340 \mathrm{~km} 2$. Di antara jajaran pulau di Nusantara, pulau Madura termasuk di antara daerah yang kering, tandus, tidak hijau, kurang subur. Ini disebabkan karena kondisi tanahnya yang kurang baik untuk tetumbuhan, pulaunya yang kecil sehingga sungaisungainya pendek, pegunungan atau bukit kapur dengan ketinggian sekitar $470 \mathrm{~m}$ di atas permukaan laut (Djakfar, 2009: 125).

Karena kondisi geografis yang demikian itulah bisa menjadi sebab Madura beriklim panas, dengan suhu udara ketika musim hujan berkisar pada angka 28 derajat celcius dan pada musim kemarau rata-rata 35 derajat celcius (De Jonge, 1989: 8).

\section{Tradisi Toron: Pemetaan Motif}

Jika dilihat dari segi motif, tradisi toron bagi etnis Madura mengandung makna tersendiri. Toron hanya berlaku bagi mereka yang melakukan migrasi keluar Pulau Madura yang dikenal dengan istilah onggha. Dengan demikian bagi etnis Madura yang tidak melakukan onggha tidak berlaku istilah toron karena tidak ke mana-mana untuk merantau ke negeri orang. Ini berarti istilah toron yang secara harfiah berarti "turun", baru ada setelah ada, atau berhadapan dengan peristiwa onggha yang secara harfiah berarti "naik".

Dikatakan "onggha/naik", menurut Humaidi, salah seorang kyai Sampang yang biasa berdakwah di Surabaya, karena dengan onggha etnis Madura bisa naik taraf perekonomiannya jika dibandingkan dengan masa sebelumnya. Karena itu menurut Muhaimin, pengasuh pesantren Darut Tauhid Injelan Sampang, bagi mereka yang sudah bertekad melakukan onggha, bagaimanapun harus sukses di rantau orang. Inilah nampaknya yang memicu semangat etnis Madura bekerja keras, ulet, dan pantang menyerah dalam bekerja apapun dengan prinsip asal menghasilkan. Sehingga benar pendapat Afif Hasan, akademisi asal Sumenep, yang menyatakan bahwa orang Madura di rantau tidak mencari pekerjaan, namun mengejar hasil.

Karena keberhasilan itu sendiri merupakan sebuah taruhan harga diri, 
apalagi sudah merantau jauh dari kampung halaman. Perasaan seperti ini yang dirasakan oleh Imam, penjual sate di kota Malang yang sebelumnya pernah bermigrasi ke Jakarta. Kadhung jhau pak lamon ta' hasel todus (terlanjur merantau jauh pak, kalau tidak suskes ya malu juga). Demikian Imam mengekspresikan parasaannya sebagai perantau bersama keluarganya. Ekspresi perasaan Imam ini, nampaknya merupakan representasi dari perasaan etnis Madura pada umumnya, terutama yang bermigrasi ke luar pulau Madura.

Berkaitan dengan motif toron sebagai realisasi perasaan rindu kampung halaman, menurut Syamsul Arifin yang paling pokok adalah pada saat hari raya (tellasan aghung moso ajjih) setelah setahun bekerja di luar Madura. Tellasan bagi etnis Madura mengandung makna sakral karena setidaknya dengan momen ini mereka manfaatkan minta sapora (minta maaf) kepada sanak keluarga, selain juga untuk nyalase (ziarah kubur) kepada leluhur, terutama kedua orang tua.

Motif lain bisa disimpulkan dari pengamatan Rifai bahwa orang Madura toron tidak sebatas karena tellasan, namun juga karena hari-hari besar Islam yang lain, seperti Maulud Nabi Muhammad SAW, Isra' Mi'raj, dan Nuzulul Quran. Kenyataan ini diamini oleh Darwis, Sumberanyar Pamekasan, yang menyatakan bahwa selama ini dalam momen-momen tersebut orang Madura masih bisa menyempatkan diri untuk toron.

Tidak demikian, menurut Sol, pengasuh pesantren Assirojiyyah Sampang, selain motif tersebut masih banyak motif lain, yaitu karena acara kematian (ta'ziyah), pernikahan anggota keluarga, keberangkatan dan kepulangan ibadah haji (ajjiyan). Namun demikian menurut Sol, yang paling pokok menjadi magnit toron-nya etnis Madura, selain tellasan, yakni acara Maulud Nabi SAW, Perkawinan, dan Haji. Salah satu di antara ketiganya menurut pandangan Sol, yang terbiasa menerima undangan dari masyarakat, adalah acara Maulud Nabi.

Pandangan Sol ini diamini oleh pendapat Darwis, yang menyatakan bahwa acara Maulud adalah acara keagamaan yang sangat dihormati oleh orang Madura, baik yang ada di Madura maupun mereka yang dirantau orang. Ada makna di balik acara ini sehingga etnis Madura yang di rantau menyempatkan diri untuk pulang kampung (toron). Karena toron sejatinya juga merupakan momen unjuk kemampuan ekonomi yang diekspresikan bagaimana cara berpakaian istri, suami, dan anak, termasuk kendaraan yang digunakan. Demikian, Sol menjelaskan. 


\section{Makna Maulud Nabi: Memahami Pertautan Tradisi Toron dengan Etos Bisnis}

Kepulangan etnis Madura ke kampung halaman (toron) dalam rangka peringatan Maulud Nabi sangatlah fenomenal sekali yang tidak jarang membuat pulau Garam itu bagaikan suasana hari raya. Hanya saja kepulangan mereka, terutama dari kalangan daerah pinggiran, tidaklah dalam skala massif sebagaimana menjelang hari raya, terutama setiap akhir Ramadhan atau awal Syawal setiap tahun. Ketidakbersamaan kepulangan mereka, menurut Humaidi, karena masyarakat yang akan mengadakan Maulud di kampung halamannya masing-masing menyesuaikan diri dengan jadwal aktivitas di daerah rantau. Dengan demikian acara peringatan yang diadakan di masing-masing rumah mereka di Madura pasti tidak bersamaan. Hanya saja rentang waktu untuk acara itu bisa mencapai satu bulan Rabiul Awal, atau lebih, tergantung mereka dalam memilih waktu sesuai kesempatan masing-masing

Menurut Muhamin dan Darwis tidaklah semua migran Madura mengadakan acara Maulud secara individual di daerah asal (pathobin), karena sebagian dari mereka tidaklah sedikit yang hanya titip sumbangan untuk acara di masjid kampung mereka, sebagaimana tradisi di daerah Socah Bangkalan. Katakan saja yang sering mengadakan acara sendiri seperti H.Maimun (asli Blega, pengusaha mebel), H.Musleh (asal Blega, pengusaha toko besi), $\mathrm{H}$. Nizar (asal Torjun, pengusaha ponten), H.Amir (asal Blega, pengusaha besi dan bongkaran), H.Halili (asli Kwanyar, pengusaha soto), dan Syahrondi (asal Torjun, pengusaha mie). Para pengusaha di Surabaya ini seringkali mengadakan acara Maulud di daerah asal masing-masing dengan mengundang kyai di mana mereka pernah mondok.

Bahkan tidak jarang yang mengadakan peringatan di rantau dengan mengundang kyai mereka. Seperti menurut pengakuan Sol dan Atho', setiap tahun diundang ke Pontianak Kalimantan selama kurang lebih satu bulan, antara lain dalam rangkaian acara Maulud yang diadakan oleh mantan santrinya yang merantau ke daerah tersebut.

Adapun rangakaian acara peringatan Maulud di Madura secara umum polanya sama, sebagaimana yang pernah diikuti peneliti 11 Februari 2012 di Kelurahan Dalpenang Sampang, yakni diawali dengan pembacaan surat al Fatihah, dilanjutkan dengan pembacaan syarofal anam (shalawat), dan baru ditutup dengan doa, tanpa mau'idah hasanah. Setelah itu acara ramah-tamah, makan bersama, dan baru berakhir para undangan pulang dengan membawa berkat yang telah disiapkan oleh shahibul bait (tuan rumah). 
Menurut Ilyas (purnawirawan polisi-Sumenep), kualitas hidangan (konsumsi) dan jumlah yang diundang mencerminkan kemampuan ekonomi tuan rumah, sekaligus merupakan gengsi dan harga diri mereka selaku orang Madura yang sukses di rantau orang. Karena itu, pada umumnya, pada bulan Maulud, orang Madura pedesaan yang di rantau menyempatkan diri mudik (toron) hanya untuk acara selamatan Maulud. Bagi mereka mengadakan acara Maulud seakan-akan wajib syar'i, bahkan kalau perlu berhutang, jika sekiranya perdagangan lagi sepi demi gengsi di mata masyarakat, kata Ilyas melanjutkan. Sebagai ekspresi kecintaannya kepada nabi, acara Maulud dianggap sebagai momen haul Rasulullah yang harus diperhatikan. Bahkan oleh sebagian mereka, menurut Humaidi, untuk memperoleh syafaat atau penebus dosa kelak di akhirat.

Selanjutnya menurut Muhaimin dan Darwis, acara Maulud yang tanpa mau'idah hasanah itu karena sedemikian padatnya jadwal kyai untuk acara yang sama. Seorang kyai, seringkali setelah selesai menghadiri acara Maulud di satu rumah dilanjutkan pindah ke acara yang sama di rumah penduduk yang lain secara bergiliran. Demikian seterusnya, sebagai tradisi tahunan di desa Prajjan Camplong dan sebagian kecamatan kota Sampang, seperti di kelurahan Barisan, Karangentang, dan Pleyang.

Bahkan menurut Saniri, mantan pengawas madrasah yang lama bertugas di Omben Sampang yang diperkuat Marzuki (pensiunan guru, menetap di Omben), di daerah Omben, Camplong, Kedungdung, dan Tambelangan kadangkala peringatan berlangsung selama tiga bulan. Yakni sebelum dan sesudah bulan Maulud untuk menyesuaikan diri antara kesempatan tuan rumah dengan kyai yang akan diundang. Demikian pula di daerah Blega (Bangkalan) dan Proppo (Pemekasan) pada umumnya terjadwal, tidak seperti daerah Ketapang sebagaimana keempat kecamatan di Kabupaten Sampang di atas. Demikian menurut Abd. Majid (Tanjungbumi Bangkalan).

Selanjutnya, apa makna peringatan Maulud menurut pemahaman mereka, antara lain dapat ditangkap pernyataan $\mathrm{H}$. Holili bahwa acara Maulud ibarat haul untuk nabi. Sapaneka pak, monggu kaom santre, amolod pada sareng nylameddi otaba ngeholeh Rasulullah. Masa' pak, oreng seppo duwa' eyehhole, pas Nabbinah bunten, kan ta' sae (begini pak, di kalangan santri, mengadakan acara Maulud ibarat melakukan haul bagi Rasulullah. Jika kedua orang tua kita yang telah meninggal, kita adakan haul, mengapa nabi kita tidak, kan tidak baik). Selanjutnya ia menjelaskan, pasera oneng kalaban shalawat se ebaca lantaran daddi tambanah rahmat kaangguy ngaolle syafaat epon Rasulullah bingkengan neng akherat 
(siapa tahu dengan pembacaan shalawat kepada nabi, kita akan mendapat rahmat sebagai jalan memperoleh syafaat dari Rasulullah kelak di akhirat).

Sejalan dengan pernyataan Holili, Nizar menambahkan, badha jugan pak amolod ca'epon kaangguy nebus dusah, sala la ta' ngalakone rokon Islam pasera oneng kalaban amolod daddi lantaran ngaolle syafaat dari Rasulullah (ada juga pak yang mengatakan bahwa mengadakan Maulud adalah sebagai penebus dosa untuk mendapat syafaat, sekalipun tidak melakukan rukun Islam). Neka kan ta' lerres pak, monggu oreng santre, masa ta' asalat, ta' apasah, namong klaban amolod pas lebbur dusanah (menurut kaca mata santri, itu kan tidak benar pak, apakah iya, hanya dengan memperingati Maulud, dosanya bisa terhapus, padahal ia tidak shalat, tidak puasa, sebagaimana yang diajarkan oleh Rasulullah), kata Majid.

Karena itu menurut $\mathrm{H}$. Arif yang benar, mengadakan Maulud haruslah dengan niat yang benar dan harta yang kita keluarkan sebagai biaya acara tidak akan ada nilainya jika kita tidak berniat menghormati Rasul kita. Pasera oneng klaban amolod rejekke sajan epagampang amarga cinta da' Rasulullah, kan enggi pak, (siapa tahu dengan memperingati Maulud rejeki akan semakin bertambah, karena kita mencintai Rasul, kan begitu pak). Se poko' yakin pak, insya Allah barakah (yang penting yakin pak, insya Allah harta kita akan barakah), demikian Arif meyakinkan kita. Nampaknya dari pernyataan ini dapat dipahami, ada pertautan antara tradisi toron dengan etos bisnis di kalangan etnis Madura.

\section{Simpulan}

Dalam setahun sekali, peringatan Maulud, ternyata merupakan salah satu motif keagamaan yang turut mendorong etnis Madura untuk pulang kampung (toron), terutama di kalangan komunitas pedesaan. Selama bulan Maulud, dapat diamati betapa banyak mereka pulang ke desa masing-masing (pathobin) dengan niat untuk memperingati kelahiran Rasulullah yang menurut mereka wajib dihormati. Pola acara peringatan di Madura nampaknya sama, yakni diawali dengan pembacaan suratul fatihah, dilanjutkan dengan pembacaan syarofal anam, dan baru diakhiri dengan doa oleh kyai, tanpa mau'idah hasanah. Setelah itu dilanjutkan dengan ramah tamah untuk menikmati berbagai sajian yang mencerminkan status sosial dan harga diri shahibul hajah (pengundang).

Bagi sebagian mereka dari kalangan santri, mengadakan Maulud di rumah masing-masing ibarat mengadakan haul untuk Rasulullah atas dasar prinsip, jika kedua orang tua dihormati, justru mengapa Rasulullah tidak diperlakukan sama. Sebab itu dengan rasa hormat inilah diharapkan kelak mereka akan 
mendapat syafaat dari Rasulullah dan akan digampangkan rezekinya. Tidak demikian dengan mereka yang nonsantri, kendati tidak melakukan perintah agama, dengan memperingati Maulud, diharapkan dosa mereka akan terhapus karena kelak akan mendapat syafaat dari Rasul.

Dengan demikian, peringatan Maulud merupakan magnit bagi etnis Madura untuk mudik ke kampung halaman (toron) sebagai sebuah tradisi secara turun-temurun. Dengan melakukan tradisi inilah mereka dapat unjuk diri kepada keluarga dan tetangga teparo bahwa dirinya sukses di rantau orang yang dapat diperlihatkan pada kesemarakan acara Maulud di rumah masing-masing. Dari sinilah kiranya dapat dipahami bahwa nampaknya tradisi toron yang telah membudaya yang antara lain termotivasi dengan peringatan Maulud dapat memacu etnis Madura untuk bekerja keras di negeri orang, yakni sebagai bagian dari harga diri yang harus dipertaruhkan di tengah masyarakat mereka.

Selain itu, lebih jauh dapat dipahami bahwa bagaimanapun kerja keras etnis Madura tidak lepas karena ajaran agama yang mereka anut, selain juga karena nilai ajaran tradisi yang telah lama hidup di kalangan mereka. Akhirnya dari tradisi toron itulah dapat dipahami pada hakikatnya ada pertautan antara agama, budaya, dan etos bisnis di kalangan etnis Madura.

\section{Daftar Pustaka}

Abdullah, Taufik (Ed.). 1979. Agama, Etos Kerja, Perkembangan Ekonomi. Jakarta: LP3ES.

Data Kanwil Kemenag Jawa Timur Bidang Pendidikan Keagamaan Pondok Pesantren. 2012.

De Jonge, Huub. 1989. Madura dalam Empat Zaman: Pedagang, Perkembangan Ekonomi, dan Islam. Jakarta: PT Gramedia.

Djakfar, Muhammad. 2009. Anatomi Perilaku Bisnis Dialektika Etika dengan Realitas. Malang: UIN-Malang Press.

Dhavamony, Mariasusi. 1995. Fenomenologi Agama. Yogyakarta: Penerbit Kanisius.

Effendy, Bahtiar. 2001. Pertumbuhan Etos Kerja Kewirausahaan dan Etika Bisnis di Kalangan Muslim dalam Bahtiar Effendy. Masyarakat Agama dan Pluralisme Keagamaan. Yogyakarta: Galang Press.

el Harakah Vol.14 No.1 Tahun 2012 
Kesuma, Andi Ima. 2004. Migrasi Eु Orang Bugis. Yogyakarta: Penerbit Ombak.

Kuntowijoyo. 2002. Madura 1850-1940. Yogyakarta: Mata Bangsa.

Langsdorf, Lenore and Stephen H. Watson with E. Marya Bower (Eds.). 1996. Phenomenology, Interpretation, and Community. Albany, N.Y.: State University of New York Press.

Lee, Evert S. 1976. Suatu Teori Migrasi, terjemahan, Yogyakarta: Lembaga Kependudukan Universitas Gadjah Mada.

Lee, Sun-Hee. 1985. Why People Intend to Move: Individual and Community-Level Factors of Out-Migration in the Philippines. London: Westview Press.

Rifai, Mien Ahmad. 2007. Manusia Madura Pembawaan, Perilaku, Etos Kerja, Penampilan, dan Pandangan Hidupnya seperti Dicitrakan Peribahasanya. Yogyakarta: Pilar Media.

Soeroso. 1996. Orang Madura dalam Kewiraswastaan, dalam (Ed.) Aswab Mahasin, et.al. Ruh Islam dalam Budaya Bangsa: Aneka Budaya di Jawa. Jakarta: Yayasan Istiqlal.

Subaharianto, Andang, dkk. 2004. Tantangan Industrialisasi Madura Membentur Kultur, Munjunjung Leluhur. Malang: Bayumedia Publishing.

Triyuwono, Iwan. 2009. Spiritualitas Etos Kerja dan Etika Bisnis Oreng Meddhurah dalam Muhammad Djakfar. 2009. Anatomi Perilaku Bisnis: Dialektika Etika dengan Realitas. Malang: UIN Malamg Press.

Wiyata, A. Latief. 2002. Carok: Konflik Kekerasan dan Harga Diri Orang Madura. Yogyakarta: LkiS. 